\title{
Penyuluhan Kesadaran Hukum Tentang Regulasi Alasan Perceraian dalam Hukum Perkawinan Islam bagi Keluarga Penerima Manfaat (KPM) Program Keluarga Harapan (PKH) di Kabupaten Grobogan
}

\author{
Daud Rismana \\ Universitas Islam Negeri Walisongo Semarang \\ Email: daudrismana@walisongo.ac.id
}

\begin{abstract}
Found Beneficiary Families (KPM) The Family of Hope Program (PKH) whose marriage ties have been shaken, some even claim to have long been abandoned by their partners without news and certainty about the continuation of their marriage ties. So they can only surrender to accept the situation without knowing what to do. These problems are due to lack of knowledge and understanding of the reasons for divorce in Islamic marriage law. Then there is no opportunity yet to get legal awareness about the reasons for divorce in Islamic marriage law. As well as from both of these concerns, legal violations occur intentionally or unintentionally. The method used in this service is the lecture method, the discussion method, and the evaluation method. This training and outreach activity produced the first conclusion, this activity was very needed and was beneficial for PKH Beneficiary Families in Wirosari District. Secondly, There is an increase in the understanding and knowledge of the participants of this activity towards the regulations or legislation regarding the reasons for divorce in Islamic marriage law in Indonesia. The third is that not all PKH KPMs in Wirosari sub-district have the opportunity to participate in this activity because of limited funds.
\end{abstract}

\begin{abstract}
Abstrak: Ditemukan Keluarga Penerima Manfaat (KPM) Program Keluarga Harapan (PKH) yang ikatan perkawinannya telah goyah, bahkan ada yang mengaku telah lama ditinggalkan oleh pasangannya tanpa kabar dan kepastian mengenai kelanjutan ikatan perkawinan mereka. Sehingga mereka hanya bisa pasrah menerima keadaan tanpa tahu harus berbuat apa. Permasalahanpermasalahan tersebut dikarenakan kurangnya pengetahuan dan pemahaman mengenai alasan perceraian dalam hukum perkawinan Islam. Kemudian belum adanya kesempatan untuk mendapatkan penyuluhan kesadaran hukum tentang alasan perceraian dalam hukum perkawinan Islam. Serta dari kedua hal tersebut dikhawatirkan terjadi pelanggaran hukum baik disengaja maupun tidak disengaja. Adapun metode yang digunakan dalam kegiatan pengabdian ini adalah
\end{abstract}


metode ceramah, metode diskusi, dan metode evaluasi. Kegiatan pelatihan dan penyuluhan ini menghasilkan kesimpulan yang pertama, kegiatan ini sangat dibutuhkan dan bermanfaat bagi Keluarga Penerima Manfaat PKH di Kecamatan Wirosari. Kedua, Terdapat peningkatan pemahaman dan pengetahuan para peserta kegiatan ini terhadap regulasi atau peraturan perundangan tentang alasan perceraian dalam hukum perkawinan islam di Indonesia. Yang ketiga adalah belum semua KPM PKH di Kecamatan Wirosari berkesempatan mengikuti kegiatan ini karena keterbatasan dana.

Kata Kunci: penyuluhan, kesadaran hukum, perceraian.

\section{PENDAHULUAN}

Perkawinan dalam Islam tidak semata-mata sebagai hubungan kontrak keperdataan biasa, namun sebagai akad yang sangat kuat (ميثاقا غليظ) untuk mentaati perintah Allah dan melaksanakannya yang merupakan ibadah. Perkawinan syarat dengan nilai dan bertujuan untuk mewujudkan kehidupan rumah tangga yang sakinah, mawadah dan rabmah (tenteram, cinta dan kasih sayang). (Abdurrahman, 1995: 114). Secara yuridis konstitusional di Indonesia, perkawinan diatur dalam Undang-Undang Perkawinan (UU.No.1/ 1974) dalam Pasal 1 sebagai berikut, Perkawinan ialah ikatan lahir batin antara seorang lakilaki dengan seorang perempuan sebagai suami istri dengan tujuan membentuk keluarga (rumah tangga) yang bahagia dan kekal berdasarkan Ketuhanan Yang Maha Esa. (S. SaptoAjie, 1990: 1).

Selanjutnya, Program Keluarga Harapan yang selanjutnya disebut PKH adalah program pemberian bantuan sosial bersyarat kepada Keluarga Miskin (KM) yang ditetapkan sebagai keluarga penerima manfaat PKH. (Permensos No 1 Tahun 2018). Sebagai upaya percepatan penanggulangan kemiskinan, sejak tahun 2007 Pemerintah Indonesia telah melaksanakan PKH. Program Perlindungan Sosial yang juga dikenal di dunia internasional dengan istilah Conditional Cash Transfers (CCT) ini terbukti cukup berhasil dalam menanggulangi kemiskinan yang dihadapi di negara-negara tersebut, terutama masalah kemiskinan kronis. (Kementerian Sosial RI, 2019: 9) Sebagai sebuah program bantuan sosial bersyarat, PKH membuka akses keluarga miskin terutama ibu hamil dan anak untuk memanfaatkan berbagai fasilitas layanan kesehatan (faskes) dan fasilitas layanan pendidikan (fasdik) yang tersedia di sekitar mereka. Manfaat PKH juga mulai didorong untuk mencakup penyandang disabilitas dan lanjut usia dengan mempertahankan taraf kesejahteraan sosialnya sesuai dengan amanat konstitusi dan Nawacita Presiden RI. Melalui PKH, KM didorong untuk 
memiliki akses dan memanfaatkan pelayanan sosial dasar kesehatan, pendidikan, pangan dan gizi, perawatan, dan pendampingan, termasuk akses terhadap berbagai program perlindungan sosial lainnya yang merupakan program komplementer secara berkelanjutan. PKH diarahkan untuk menjadi episentrum dan center of excellence penanggulangan kemiskinan yang mensinergikan berbagai program perlindungan dan pemberdayaan sosial nasional. (Kementerian Sosial RI, 2019: 9). Sesuai dengan pasal 3 Permensos RI tahun 2018, sasaran PKH merupakan keluarga dan / atau seseorang yang miskin dan rentan serta terdaftar dalam data terpadu program penanganan fakir miskin, memiliki komponen kesehatan, pendidikan, dan / atau kesejahteran sosial. (Permensos No 1 Tahun 2018).

Dalam Program Keluarga Harapan (PKH) terdapat ketentuan-ketentuan mengikat yang melekat pada KPM Program Keluarga Harapan, sehingga peserta PKH ini tidak serta merta hanya menerima bantuan sosial dari pemerintah semata tanpa adanya ketentuan lebih lanjut. PKH yang telah berlangsung sejak tahun 2007 ini terdapat hak bagi peserta PKH, kemudian juga terdapat kewajiban yang harus dilaksanakan oleh peserta $\mathrm{PKH}$, serta ada sanksi ketika peserta PKH ini tidak melaksanakan komitmen/ kewajibannya tersebut.

Sasaran PKH merupakan keluarga dan/ atau seseorang yang miskin dan rentan serta terdaftar dalam data terpadu program penanganan fakir miskin, sehingga ketika terjadi hal seperti itu akan berdampak serius terhadap keutuhan keluarga dari keluarga penerima manfaat PKH. Pada satu sisi, KPM PKH adalah sebuah keluarga yang harmonis, namun tidak bisa dipungkiri bisa terjadi gejolakgejolak yang muncul dalam sebuah ikatan perkawinan yang telah lama mereka bangun.

Tidak sedikit dijumpai adanya KPM PKH yang ternyata ikatan perkawinannya telah goyah, dan bahkan ada yang mengaku jika telah lama ditinggalkan oleh salah satu pasangannya tanpa ada kabar dan kepastian yang jelas mengenai kelanjutan ikatan perkawinan mereka. Sehingga terkadang mereka sendiri hanya bisa pasrah menerima keadaan dan kenyataan yang menimpanya tanpa tahu harus berbuat apa dan mengadu kepada siapa. Permasalahanpermasalahan hukum yang dihadapi oleh para KPM PKH tersebut disebabkan oleh beberapa faktor, yaitu yang pertama dikarenakan kurangnya pengetahuan dan pemahaman yang sangat terbatas mengenai regulasi alasan perceraian dalam hukum perkawinan islam di Indonesia. Kedua yaitu tidak atau belum ada kesempatan bagi para KPM PKH mendapatkan pelatihan dan penyuluhan kesadaran hukum tentang regulasi alasan perceraian dalam hukum perkawinan 
Islam di Indonesia. Yang ketiga adalah kurangnya pemahaman para KPM PKH tersebut tentang regulasi alasan perceraian dalam hukum perkawinan islam di Indonesia dikhawatirkan akan menimbulkan potensi pelanggaran hukum baik disengaja maupun tidak disengaja karena memang tidak mengetahui.

Permasalahan utama yang harus ditangani dengan segera yaitu perlu diberikan kesempatan kepada para KPM PKH tersebut untuk memperoleh pelatihan dan penyuluhan kesadaran hukum tentang regulasi alasan perceraian dalam hukum perkawinan islam di Indonesia baik melalui pelatihan atau pun kursus yang terstruktur.

Kegiatan pelatihan atau penyuluhan kesadaran hukum tentang regulasi alasan perceraian dalam hukum perkawinan islam di Indonesia ini melibatkan peserta sebanyak 60 (enam puluh) orang yang terdiri dari para keluarga penerima manfaat (KPM) program keluarga harapan (PKH) yang berada di desa Gedangan, Kecamatan Wirosari Kabupaten Grobogan Jawa Tengah. Alasan memilih mereka sebagai subjek dampingan diantaranya adalah pertama, mereka para keluarga penerima manfaat (KPM) program keluarga harapan (PKH) dalam aktifitas kesehariannya tidak bisa lepas dari persoalan dan permasalahan perkawinan di dalam rumah tangga mereka dan bahkan memang sudah terdapat masalah yang belum bisa diselesaikan karena kurangnya pemahaman mengenai regulasi alasan perceraian dalam hukum perkawinan islam di Indonesia, sehingga dikhawatirkan problematika tersebut akan berlarut tanpa ada penyelesaian.

Alasan yang kedua yaitu keberadaan para keluarga penerima manfaat (KPM) program keluarga harapan (PKH) tersebut yang tergabung di bawah kelompok peserta program keluarga harapan $(\mathrm{PKH})$ desa Gedangan Kecamatan Wirosari. Peran sosial bermasyarakat yang dilakukan oleh para KPM PKH tersebut dapat mempengaruhi sistem tata perilaku masyarakat umumnya dan para keluarga pada khususnya. Oleh karena itu dengan memberikan pengetahuan dan pemahaman yang cukup mengenai kesadaran hukum tentang regulasi alasan perceraian dalam hukum perkawinan islam di Indonesia tersebut juga akan memiliki dampak yang baik terhadap keutuhan ikatan perkawinan sebuah keluarga yang sudah dibangun dengan dasar kasih sayang dan cinta kasih.

Kondisi dampingan kegiatan pelatihan dan penyuluhan kesadaran hukum tentang regulasi alasan perceraian dalam hukum perkawinan islam di Indonesia ini dapat pengabdi uraikan sebagai berikut, pertama pengabdi bermitra atau bekerjasama dengan stakeholder yaitu Pelaksana Program Keluarga Harapan (PPKH) Kecamatan Wirosari Kabupaten Grobogan, yang notabene menaungi para keluarga penerima manfaat (KPM) program keluarga harapan (PKH). 
Lokasi pengabdian dengan kampus UIN Walisongo Semarang berjarak +/- 90 (sembilan puluh) $\mathrm{km}$.

Kedua, pengetahuan dan pemahaman para keluarga penerima manfaat (KPM) program keluarga harapan (PKH) yang berada di desa Gedangan Kecamatan Wirosari Kabupaten Grobogan terhadap hukum atau peraturan perundang-undangan tentang alasan perceraian dalam hukum perkawinan islam di Indonesia masih jauh dari harapan. Para KPM PKH tersebut kurang memperoleh kesempatan untuk belajar dan menerima panyuluhan tentang regulasi alasan perceraian dalam hukum perkawinan islam di Indonesia. Para KPM PKH tersebut nyaris belum mengetahui apalagi memahami aturan tentang alasan perceraian dalam hukum perkawinan islam di Indonesia. Hal ini apabila dibiarkan terus menerus akan sangat beresiko dan sangat tidak menguntungkan bagi mereka terutama kelangsungan ikatan perkawinan.

Ketiga, semua KPM PKH tersebut tidak ada yang berbasis sarjana hukum, mayoritas berpendidikan tamatan SD, SMP, dan sedikit yang lulusan SLTA, sehingga wawasan dan pengetahuan mereka sangat terbatas dan kurang. Kondisi dampingan yang diharapkan oleh kegiatan pelatihan dan penyuluhan kesadaran hukum tentang regulasi alasan perceraian dalam hukum perkawinan islam di Indonesia ini adalah terciptanya pemahaman yang utuh oleh para Keluarga Penerima Manfaat (KPM) Program Keluarga Harapan (PKH) tentang regulasi alasan perceraian dalam hukum perkawinan islam di Indonesia dan mampumengimplementasikan dalam beraktifitas sehari-hari sebagai sebuah keluarga yang harmonis dan menjaga ikatan perkawinan.

\section{STRATEGI DAN METODE PENGABDIAN}

Kegiatan pengabdian ini berupa pelatihan atau penyuluhan kesadaran hukum tentang regulasi alasan perceraian dalam hukum perkawinan Islam di Indonesia. Untuk mendapatkan kondisi dampingan yang diharapkan oleh kegiatan pengabdian ini, maka pengabdi menggunakan strategi berupa kerjasama dengan stakeholder yaitu Pelaksana Program Keluarga Harapan (PPKH) Kecamatan Wirosari Kabupten Grobogan. Kerjasama kegiatan ini meliputi perencanaan kegiatan, pelaksanaan kegiatan, dan evaluasi hasil kegiatan. Adapun tahapan-tahapannya adalah sebagai berikut, Pertama pendaftaran peserta pelatihan dan penyuluhan berdasarkan hasil koordinasi dan rekomendasi Pelaksana Program Keluarga Harapan (PPKH) Kecamatan Wirosari Kabupten Grobogan, sebanyak 60 (enam puluh) orang calon peserta berhasil diidentifikasi 
dan menjadi peserta kegiatan pelatihan dan penyuluhan kesadaran hukum tentang regulasi alasan perceraian dalam hukum perkawinan islam di Indonesia.

Kedua, sebelum mengikuti pelatihan dilakukan tes penjajakan atau tes uji coba kemampuan peserta terhadap pemahaman regulasi alasan perceraian dalam hukum perkawinan islam di Indonesia. Calon peserta terbagi dalam 3 (tiga) kelompok belajar. Ketiga, hasil darites penjajakan tersebut akan dijadikan dasar bagi instruktur dalam pengelolaan kelas pelatihan. Keempat, setelah mengikuti pelatihan semua peserta mengikuti tes akhir untuk mengukur sejauh mana penyerapan dan pemahaman peserta terhadap materi pelatihan. Hal ini penting untuk mengevaluasi keberhasilan kegiatan pelatihan ini dari aspek akademik. Kelima, melakukan evaluasi secara menyeluruh atas kegiatan pengabdian ini guna mendapatkan penilaian keberhasilan kegiatan ini dan menyusun rekomendasi untuk program pengabdian sejenis yang akan dilakukan.

Adapun metode yang digunakan dalam kegiatan pengabdian ini adalah pertama, metode ceramah yaitu narasumber menyampaikan materi-materi tentang regulasi alasan perceraian dalam hukum perkawinan Islam di Indonesia. Kedua, metode diskusi yaitu narasumber memandu diskusi tentang studi kasus dan problematika implementasi peraturan perundangan tentang regulasi alasan perceraian dalam hukum perkawinan islam di Indonesia di masyarakat khususnya di lingkungan keluarga penerima manfaat.

Ketiga, metode evaluasi yaitu pengabdi mempersiapkan bahan-bahan evaluasit entang materi regulasi alasan perceraian dalam hukum perkawinan islam di Indonesia. Metode ini pengabdi gunakan untuk mengukur tingkat penguasaan dan pemahaman peserta terhadap regulasi alasan perceraian dalam hukum perkawinan islam di Indonesia baik sebelum kegiatan pengabdian maupun setelah kegiatan pengabdian.

\section{HASIL DAN PEMBAHASAN}

Perceraian atau sering dipahami dengan "Putusnya Perkawinan" adalah berakhirnya hubungan antara suami dan istri yang telah menjalin ikatan perkawinan dikarenakan oleh suatu sebab tertentu. Dalam istilah fiqh, perceraian sering identik dengan istilah furqah. Namun penggunaan istilah "Putusnya Perkawinan" juga harus hati-hati karena pengertian perkawinan yang putus itu dalam istilah fiqh digunakan kata ba'in, yaitu suatu bentuk perceraian suami istri yang suami tidak boleh kembali lagi kepada mantan istrinya kecuali dengan melalui akad nikah yang baru. Istilah yang paling netral adalah "perceraian", namun sulit juga menggunakan istilah tersebut sebagai pengganti "putusnya 
perkawinan", karena perceraian itu sendiri sebagai salah satu bentuk dari putusnya perkawinan. (Amir Syarifudin, 2006: 189 dan Azhar Basyir, 1990: 66).

Namun beberapa ulama menafsirkan perceraian langsung menunjuk pada kata "talak" karena kebanyakan munculnya keinginan bercerai biasanya dari pihak suami. Artikulasi semacam itu menjadi kesimpulan tersendiri untuk mendekatkan definisi perceraian pada definisi talak, meskipun talak itu sendiri menjadi salah satu bentuk perceraian. Sementara perceraian yang dimaksudkan dalam hal ini adalah lepasnya ikatan perkawinan yang disebabkan oleh berbagai faktor baik yang berasal dari kedua belah pihak antara suami istri maupun dari luar kedua belah pihak semisal salah satu pihak meninggal dunia, ataupun permintaan atau tekanan dari orang-orang dekatnya.

Al-Qur'an telah mengatur secara jelas bahwa perceraian itu diperbolehkan meski tergolong sebagai tindakan yang paling dibenci oleh Allah SWT. Beberapa ayat yang menjelaskan tentang aturan dan hukum melakukan talak adalah surat Al-Baqarah (2) ayat 229 sebagaimana disebutkan di atas, dan juga surat At-Thalaq (65) ayat 1 artinya yang berbunyi, "Hai Nabi, apabila kamu menceraikan Istri-istrimu Maka hendaklah kamu ceraikan mereka pada waktu mereka dapat (menghadapi) iddahnya (yang wajar) dan bitunglah waktu iddah itu serta bertakwalah kepada Allah Tuhanmu. janganlab kamu keluarkan mereka dari rumah mereka dan janganlah mereka (diizinkan) ke luar kecuali mereka mengerjakan perbuatan keji yang terang. Itulah hukum-bukum Allah, Maka Sesunggubnya dia Telab berbuat zalim terhadap dirinya sendiri. Kamu tidak mengetahui barangkali Allab mengadakan sesudah itu sesuatu bal yang baru." (QS. At Thalaq: 1).

Maksud dari ayat tersebut di atas adalah istri-istri itu hendaklah ditalak di waktu suci sebelum dicampuri, yang mana Al-Qur'an menyebutkan hal itu dalam kondisi yang normal atau wajar. Dapat diartikan bahwa adanya suatu aturan semacam itu untukmenganjurkan pada seorang suami lebih menghormati hakhak seorang istri dan menekankan pada sisi kemanusiaan.

Regulasi tentang alasan perceraian dalam hukum positif termaktub di dalam Undang-undang No. 1 tahun 1974 tentang Perkawinan, PP No. 9 tahun 1975 tentang Pelaksanaan Undang-Undang Perkawinan, UU No. 7 tahun 1989 tentang Peradilan Agama, dan Inpres No. 1 tahun 1991 tentang Kompilasi Hukum Islam. Telah diketahui bahwa pada prinsipnya tujuan perkawinan menurut Undang-undang Perkawinan membentuk keluarga yang bahagia dan kekal. Karena itu Undang-undang ini juga mengatur asas atau prinsip mempersukar terjadinya perceraian. Untuk kemungkinan terjadinya perceraian harus ada alasan tertentu, serta dilakukan di depan sidang pengadilan (Ahmad Rofiq, 2003: 268). 
Pengadilan Agama sebagai lembaga peradilan yang berwenang menyelesaikan perkara perdata umat Islam juga telah menangani perkara perceraian-perceraian keluarga dengan berbagai macam alasan di dalamnya. Sebagaimana dalam UU RI No. 3 Tahun 2006 tentang Perubahan atas UU No. 7 tahun 1989 tentang Peradilan Agama disebutkan: PeradilanAgama adalah salah satu pelaku kekuasaan kehakiman bagi rakyat pencari keadilan yang beragama Islam mengenai perkara tertentu sebagaimana dimaksud dalam Undang-undang ini (Pasal 2). Juga, Pengadilan Agama bertugas dan berwenang memeriksa, memutus, dan menyelesaikan perkara di tingkat pertama antara orang-orang yang beragama Islam di bidang: Perkawinan; Waris; Wasiat; Hibah; Wakaf; Zakat; Infaq; Shadaqah; dan Ekonomi Syariah (pasal 49) (Direktorat Jenderal Badan Peradilan Agama Mahkamah Agung RI, 2006: 2).

Dari beberapa bentuk perceraian yang dibahas pada bagian selanjutnya, secara umum adanya perceraian menuntut harus ada alasan dan keadaan yang melatarbelakanginya. Keadaan semacam itu yang menjadi syarat dibolehkannya melakukan perceraian. Dalam hal ini baik Undang-Undang Perkawinan atau Kompilasi Hukum Islam telah sejalan dengan fiqh sebagaimana disebutkan pada pasal 39 UU Perkawinan yang terdiri dari 3 ayat dengan rumusan sebagai berikut:

a. Perceraian hanya dapat dilakukan di depan sidang pengadilan setelah pengadilan yang bersangkutan berusaha dan tidak berhasil mendamaikan kedua belah pihak.

b. Untuk melakukan perceraian harus ada cukup alasan, bahwa antara suami istri tidak akan dapat hidup rukun sebagai suami istri.

c. Tata cara perceraian di depan sidang pengadilan diatur dalam peraturan perundangan tersendiri. (Undang-undang RI No. 1 Tahun 1974 tentang Perkawinan, Pasal 39 ayat 1,2, dan 3)

Kemudian pada Pasal 39 ayat (2) UU Perkawinan dijelaskan secara singkat terinci dalam PP No. 9 Tahun 1975 pada Pasal 19 dengan rumusan yaitu perceraian dapat terjadi karena sebab atau alasan-alasan sebagai berikut:

a. Salah satu pihak berbuat zina atau menjadi pemabuk, pemadat, penjudi, dan lain sebagainya yang sukar disembuhkan.

b. Salah satu pihak meninggalkan pihak lain selama 2 (dua) tahun berturut-turut tanpa izin pihak lain dan tanpa alasan yang sah atau karena hal lain di luar kemampuannya.

c. Salah satu pihak mendapat hukuman penjara 5 (lima) tahun atau hukuman berat yang membahayakan pihak lain.

d. Salah satu pihak melakukan kekejaman atau penganiayaan berat yang membahayakan pihak lain. 
e. Salah satu pihak mendapat cacat badan atau penyakit dengan akibat tidak dapat menjalankan kewajibannya sebagai suami istri.

f. Antara suami dan istri terus menerus terjadi perselisihan dan pertengkaran dan tidak ada harapan akan hidup rukun lagi dalam rumah tangga. (Peraturan Pemerintah RI No. 9 Tahun 1975, tentang Pelaksanaan Undang-Undang No. 1 Tahun 1974 tentang Perkawinan Pasal 19)

Alasan perceraian ini adalah sama seperti yang tersebut dalam pasal 116 Kompilasi Hukum Islam dengan penambahan dua ayat yaitu (1) suami melanggar taklik talak dan (2) peralihan agama atau murtad yang menyebabkan terjadinya ketidak rukunan dalam rumah tangga.

Dari aturan-aturan tersebut di atas telah menunjukkan bahwa adanya titik temu antara Undang-Undang Perkawinan atau Kompilasi Hukum Islam dengan figh yang menekankan pada aspek keadilan dan keseimbangan kedua belah pihak antara suami dan istri. Dalam hal ini suami dan istri mempunyai porsi yang sama dalam pandangan hukum, termasuk pengaruhnya terhadap proses diperbolehkannya perceraian.

Kegiatan karya pengabdian masyarakat ini berbentuk pelatihan dan penyuluhan kesadaran hukum tetangregulasi alasan perceraian dalam hukum perkawinan islam di Indonesia. Kegiatan ini bekerjasama dengan stakeholder. Adanya stakeholder dalam kegiatan ini sangat membantu dalam perencanaan peserta kegiatan, pelaksanaan kegiatan dan evaluasi hasil kegiatan sehingga kegiatan dapat berjalan dengan baik dan lancar. Adapun stakeholder dalam kegiatan ini yaitu Pelaksana Program Keluarga Harapan (PPKH) Kecamatan Wirosari Kabupaten Grobogan yang notabene mempunyai tugas dan fungsi dari Kementerian Sosial RI untuk menaungipara peserta Program Keluarga Harapan $(\mathrm{PKH})$ yang dimana peserta dalam kegiatan ini adalah para Keluarga Penerima Manfaat (KPM) dari peserta PKH tersebut. Dipilihnya Pelaksana Program Keluarga Harapan (PPKH) Kecamatan Wirosari Kabupaten Grobogan karena (1) PPKH ini menaungi banyak Keluarga Penerima Manfaat (KPM) Program Keluarga Harapan (PKH) yang jumlahnya lebih dari tiga ribu KPM yang tersebar se Kecamatan Wirosari Kabupaten Grobogan. (2) banyak Keluarga Penerima Manfaat (KPM) Program Keluarga Harapan (PKH) belum sepenuhnya memahami peraturan perundangan tentang regulasi alasan perceraian dalam hukum perkawinan islam di Indonesia (3) Pelaksana Program Keluarga Harapan (PPKH) Kecamatan Wirosari siap bekerjasama untuk sukses terselenggaranya kegiatan pengabdian ini. 
Peserta kegiatan ini sebanyak 60 (enam puluh) orang yang terdiri dari Keluarga Penerima Manfaat (KPM) Program Keluarga Harapan (PKH) di Desa Gedangan Kecamatan Wirosari Kabupaten Grobogan. Kegiatan pelatihan dan penyuluhan kesadaran hukum tentang regulasi alasan perceraiandalam hukum perkawinan islam di Indonesiaini telah dilaksanakan pada hari Sabtu, tanggal 29 Juni 2019, mulai jam 07.00 sampai dengan jam 17.00 WIB, bertempat di Rumah Peserta PKH Desa Gedangan Kecamatan Wirosari Kabupaten Grobogan. Dipilihnya lokasi kegiatan di Rumah Peserta PKH ini karena rumah tersebut dinilai sudah cukup memadai untuk mendukung terlaksananya kegiatan ini dan lokasi Rumah Peserta PKH ini berada di tengah-tengah pusat desa, sehingga memudahkan jangkauan kehadiran para peserta kegiatan ini.

Diskusi studi kasus dan problematika implementasi peraturan perundangan tentang regulasi alasan perceraian dalam hukum perkawinan islam di Indonesia ini sangat menarik diikuti oleh para peserta. Suasana sangat hidup dan masing-masing peserta sangat aktif menceritakan berbagai hal problematika yang ada di lingkungan keluarga masing-masing. Setelah identifikasi problematika kemudian dicari solusi pemecahannya agar sesuai degan hukum yang berlaku di Indonesia. Setelah sesi diskusi ini selesai kemudian diadakan review atas materi-materi yang telah didapatkan sejak pagi. Review materi ini sangat penting untuk merefresh penyerapan peserta atas materi kegiatan yang telah disampaikan oleh narasumber guna membantu kesiapan peserta untuk mengerjakan evalusi penyerapan materi melalui uji tes akhir.

Sebelum pelaksanaan kegiatan pelatihan dan penyuluhankesadaran hukum tentang regulasi alasan perceraian dalam hukum perkawinan islam di Indonesiaini telah dilakukan evaluasi atau pretest atau tes uji coba terhadap semua peserta.Maksud evaluasi pretest ini adalah untuk mengukur tingkat penguasaan dan pemahaman peserta terhadap tentang regulasi alasan perceraian dalam hukum perkawinan islam di Indonesia khususnya Peraturan Pemerintah Nomor 9 Tahun 1975 dan Kompilasi Hukum Islam.

Hasil evaluasi pretest menunjukkan bahwa tingkat pemahaman peserta terhadap Peraturan Pemerintah Nomor 9 Tahun 1975 tentang pelaksanaan Undang-Undang Perkawinan sangat rendah yaitu nilai rata-rata yang diperoleh skor 3 dari total skor 10 . Hasil dari pretest ini dijadikan dasar bagi narasumber atau instruktur dalam pengelolaan kelas pelatihan dan penyuluhan ini.

Semua peserta mengikuti tes akhir pelatihan untuk mengukur sejauh mana penyerapan dan pemahaman peserta terhadap materi pelatihan. Hal ini penting untuk mengevaluasi keberhasilan kegiatan pelatihan ini dari aspek akademik. Hasil evaluasi tes akhir menunjukkan bahwa tingkat pemahaman 
peserta terhadap tentang regulasi alasan perceraian dalam hukum perkawinan islam di Indonesia mengalami peningkatan yang cukup signifikan yaitu nilai ratarata yang diperoleh skor 7 dari total skor 10 .

Secara umum pelaksanaan kegiatan pelatihan dan penyuluhan kesadaran hukum tentang regulasi alasan perceraian dalam hukum perkawinan islam di Indonesia ini berjalan relatif baik dan lancar. Meskipun demikian terdapat beberapa hambatan yang mempengaruhi secara tidak langsung terhadap jalannya kegiatan ini, di antaranya yaitu, 1) Jumlah kuota peserta kegiatan ini tidak sebanding dengan jumlah KPM PKH di wilayah Kecamatan Wirosari Kabupaten Grobogan. Penentuan KPM PKH siapa saja yang berkesempatan mengikuti kegiatan ini terjadi perbedaan pendapat.Ada usulan agar diprioritaskan KPM PKH reguler (yang mempunyai komponen ibu hamil, anak balita, dan anak sekolah) dan sebagian KPM PKH yang sudah lansia (lanjut usia), kalau masih ada sisa kuota baru diikutkan KPM PKH penyandang disabilitas berat. Karena materi kegiatan ini mencakup tentang regulasi alasan perceraian, maka diputuskan bahwa peserta kegiatan ini harus yang masih berstatus suami-istri dengan perbandingan secara proporsional. Adapun sisa KPM PKH yang belum mengikuti kegiatan ini akan diusulkan untuk mengikuti kegiatan sejenis yang akan diselenggarakan di masa-masa yang akan datang. 2) Keterbatasan dana yang tersedia sehingga pelaksana harus berhemat-hemat dan seefisien mungkin agar kegiatan ini dapat berjalan dengan baik dan lancar

\section{KESIMPULAN}

Dari paparan laporan pelaksanaan kegiatan penyuluhan kesadaran hukum tentang regulasi alasan perceraian dalam hukum perkawinan islam di Indonesiadi Kecamatan Wirosari Kabupaten Grobogan yang berbentuk pelatihan dan penyuluhan ini dapat disimpulkan; Kegiatan ini sangat dibutuhkan dan bermanfaat bagi Keluarga Penerima Manfaat (KPM) Program Keluarga Harapan (PKH) di Kecamatan Wirosari Kabupaten Grobogan; Terdapat peningkatan pemahaman dan pengetahuan para pesertakegiatan ini terhadap regulasi atau peraturan perundangan tentang alasan perceraian dalam hukum perkawinan islam di Indonesia. Hal ini dibuktikan dengan adanya peningkatan skor tes hasil evaluasi yaitu nilai rata-rata dari 3 menjadi 7; Belum semua Keluarga Penerima Manfaat (KPM) Program Keluarga Harapan (PKH) di Kecamatan Wirosari Kabupaten Grobogan tersebut berkesempatan mengikuti kegiatan ini karena keterbatasan dana. Diharapkan ada pendanaan kegiatan sejenis untuk tahun yang akan datang sehingga semua Keluarga Penerima 
Manfaat (KPM) Program Keluarga Harapan (PKH) yang belum berkesempatan mengikuti kegiatan ini berkesempatan untuk bisa mengikuti kegiatan sejenis di tahun yang akan datang.

\section{DAFTAR PUSTAKA}

Abdurrahman. 1995. Kompilasi Hukum Islam di Indonesia. Jakarta: Akademika Pressindo.

Basyir Azhar.1990. Hukum Perkawinan Islam. Yogyakarta: Perpustakaan Fak. Hukum UII.

Ghazali Abdul Rahman. 2010. Fiqih Munakahat. Jakarta: Prenada Media Group.

Rofiq Ahmad. 2003. Hukum Islam Di Indonesia. Jakarta: PT. Raja Grafindo Persada. Cet-6,

S.SaptoAjie (ed.). 1990. UU Perkawinan (UU.No.1Tahun1974). Semarang: CV. Aneka Ilmu.

Syarifudin Amir. 2006. Hukum Perkawinan Islam di Indonesia: Antara Fiqh Munakahat dan Undang-undang Perkawinan. Jakarta: Kencana.

Departemen Agama RI Dirjen Bimas Islam Direktorat Urusan Agama Islam Dan Pembinaan Syariah. 2007. Al-Qur'an dan Terjemahnya. Jakarta: CV. Nala Dana.

Permensos No 1 Tahun 2018

Kementerian Sosial RI. 2019. Pedoman pelaksanaan PKH tabun 2019.

Direktorat Jenderal Badan Peradilan Agama Mahkamah AgungRI. 2006. UndangUndang Republik Indonesia No. 3 Tabun 2006 tentang Perubahan atas Undang-undang No. 7 tabun 1989 tentang Peradilan Agama. Jakarta: Panitia Kegiatan Sosialisasi UU RI No. 3 Tahun 2006 tentang Perubahan atas UU No. 7 tahun 1989 tentang Peradilan Agama.

Peraturan Pemerintah RI No. 9 Tahun 1975, tentang Pelaksanaan UndangUndang No. 1 Tahun 1974 tentang Perkawinan. 